\title{
Information concernant le chapitre retiré de la publication : Actualité de Madame de Staël et de Simone de Beauvoir. Regards croisés sur les origines du féminisme depuis 1945. (p. 159, André Leblanc)
}

André Leblanc

The publisher is retracting and removing the chapter Leblanc (2015) due to infringement of copyright.

The editors and the publisher were contacted by the author of said chapter after alleged infringement of copyright. The author was found to have used parts of a text without permission from the original author, or giving proper reference to that work.

Results of the investigation carried out by the ethics committee at the author's university confirmed the allegations that parts of the original text were indeed similar to particular passages in the published chapter.

After consulting the COPE's Retraction Guidelines and after reading the investigation from the university, it was determined that the level of similarity and the degree of overlap between the two chapters lead to a decision to retract the above referenced work from publication.

The Editors of the book have taken all reasonable precautions to prevent this from happening, and the misconduct was not detected during the peer-review process due to the original text not being made available by publication.

The publisher and the book editors sincerely regret any inconvenience this might have caused to the readership, and have thus issued a new version of the book to be found at: http://dx.doi.org/I0.16993/bad.

Retracted on 17 June 2016.

\section{Bibliographie}

Leblanc, A. 2015. Actualité de Madame de Staël et de Simone de Beauvoir.

Regards croisés sur les origines du féminisme depuis I945. In: Cedergren,

How to cite this book chapter:

Leblanc, A. 20 I 5. Information concernant le chapitre retiré de la publication : Actualité de Madame de Staël et de Simone de Beauvoir. Regards croisés sur les origines du féminisme depuis 1945. (p. 159, André Leblanc). In: Cedergren, M. et Briens, S. (eds.) Médiations interculturelles entre la France et la Suède. Trajectoires et circulations de I945 à nos jours. Pp. 296-297. Stockholm: Stockholm University Press. DOI: http:// dx.doi.org/Io.16993/bad.v. License: CC-BY 
M. et Briens, S. (eds.) Médiations interculturelles entre la France et la Suède. Trajectoires et circulations de I945 à nos jours. Pp. I59-I73. Stockholm: Stockholm University Press. DOI: http://dx.doi.org/Io.I6993/bad.m. License: CC-BY 